\title{
THE INFLUNCE OF WHEAT HARDNESS ON ENERGY CONSUMPTION DURING THE WHEAT MILLING
}

\author{
Zeyad AHMED ${ }^{1}$, Rafal NADULSKI ${ }^{2}$, Marian PANASIEWICZ ${ }^{2}$ \\ ${ }^{1}$ Department of Machines and Equipment, University of Baghdad, IRAQ \\ ${ }^{2}$ Department of Food Engineering and Machines, University of Life Sciences, POLAND \\ E-mail of corresponding authors: ziadarif@yahoo.com,rafal.nadulski@up.lublin.pl
}

Keywords: hardness, milling, specific energy, efficiency

\begin{abstract}
Wheat is generally used for a food after converting grain components into different degrees of flour. The perfect milling operation needs to get enough knowledge about kernel mechanical properties and mainly hardness, to estimate correctly its effect on grinding performance. This study determined the influence of wheat hardness on milling energy and efficiency. The results showed great effect of wheat hardness on milling performance. The lowest values of specific energy were recorded in the case of cultivar Katoda. This cultivar is characterised by the lowest value of hardness index. The study indicates that, it is possible to select cultivars with low specific energy and high efficiency during milling, which in effect will cause a reduction of production costs.
\end{abstract}

\section{INTRODUCTION}

Since the dawn of agriculture, wheat has been the major source of food and calories for mankind worldwide (Krasileva, Vasquez-Gross, Howell, Bailey, Paraiso, Clissold, Simmonds, Ramirez-Gonzalez, Wang, Borrill, Fosker, 2017). It is a leading source of protein in a human diet for its high protein content (Bhat, Wani, Hamdani, Gani, Masoodi, 2016). Examining the mechanical properties of wheat grain shows the way to optimize the machine designs and helps us determine the forces endured by wheat grains through milling process and leads to advance improvements make possible for us to drive an innovation process, (Ahmed, Nadulski, Kobus, Zawiślak, 2015). Grinding wheat is one of the oldest techniques of food processing, (Hourston, Ignatz, Reith, Leubner-Metzger, Steinbrecher, 2017), in which wheat endosperm is gradually grinded to a particular size range of flour through a progressive size-reduction process, (Patwa, Malcolm, Wilson, Ambrose 2014). Although several types of milling machines are used now, but, the most common is roller mill which grind by share and compression forces to get wide reduction of particle size (Dziki, 2011). The energy consumption through wheat milling operation has attracted a lot of scientist attentions. Consuming energy during wheat grinding operation is the highest in whole cereal industry processing (Dziki, Laskowski, 2005). Grinding energy and flour yield are affected extensively by tempering [Warechowska, 2014) and hardness (Dziki, Cacak-Pietrzak, Miś, Jończyk, Gawlik-Dziki, 2014). On the other hand, energy consumption of grain grinding depends mainly on kernel hardness, which defined as the ratio of rupture force to the deformation at the rupture point of the grain that achieved by Instron machine test (Başlar, Kalkan, Kara, Ertugay, 2012), and influenced by different factors such as moisture content (Clarke, Rottger, 2016). The energy consumption and final product specification are the main indicators for both producer and consumer (Raigar, Prabhakar, Srivastav, 2017). Thus, specific grinding energy in the milling operation is calculated as the ratio of the grinding energy to the mass of the wheat used to grind (Dziki, Laskowski, 2010). The milling efficiency is an important indicator to define wheat milling performance, (Warechowska, Warechowski, Skibniewska, Siemianowska, Tyburski, Aljewicz, 2016). The values of milling efficiency index are decrease with medium-hard wheat, but increase with hard wheat but 
Warechowska, Markowska, Warechowski, Miś, Nawrocka (2016) and Dziki, PrzypekOchab (2009) showed a significant effect of the hardness for seven bread wheat grain on grinding efficiency index, and concluded that increasing the grain hardness leads to decrease the grinding efficiency index.

The aim of this study was to reflect more information about the influence of wheat hardness on milling performance. The parameters used to determine machines performance during milling operation were specific energy and milling efficiency.

\section{MATERIAL AND METHODS}

The investigations were carried out on three Polish spring wheat cultivars (Triticum aestivum, ssp. Vulgare): Arabella, Kandela and Katoda, harvested in 2016, acquired from the plant breeding station DANKO Hodowla Roślin Sp. z o.o. in Chorynia. An analyser of single seeds (SKCS 4100, Perten, Sweden) was used to determine moisture content, mass, substitute diameter and hardness index of single seeds. In this study, three levels of moisture content of wheat kernels were determined: $12 \%, 14 \%$, and $16 \%$. In order to reach these levels, the grain was conditioned by adding specific amounts of water and mixed several times to ensure good distribution of added water for all kernels. The damped grains were isolated in separated containers for 3 days under normal laboratory temperature of $24 \pm 2^{\circ} \mathrm{C}$. The grain was ground using a roller mill of the type Quadrumat ${ }^{\circledR}$ Junior (C.W. Brabender ${ }^{\circledR}$ Instruments, Inc., USA). The mill worked in conjunction with a computer system recording the power consumption. The parameters determined in the tests were the specific energy and efficiency of milling, specific energy is the energy used during the milling operation divided by the mass of the flour produced, while the efficiency was the mass of wheat divided by time required for the milling operation. Statistical analysis of the results was made using the software package Statistica 12.0 (StatSoft Inc., Tulsa, OK, USA), using the analysis of variance The significance of differences was verified using the Fisher LSD test.

\section{RESULTS}

The study demonstrated a statistically significant effect of cultivar traits of the wheat cultivars studied on hardness index. The results obtained by single kernel analysing are showed in Figure 1.
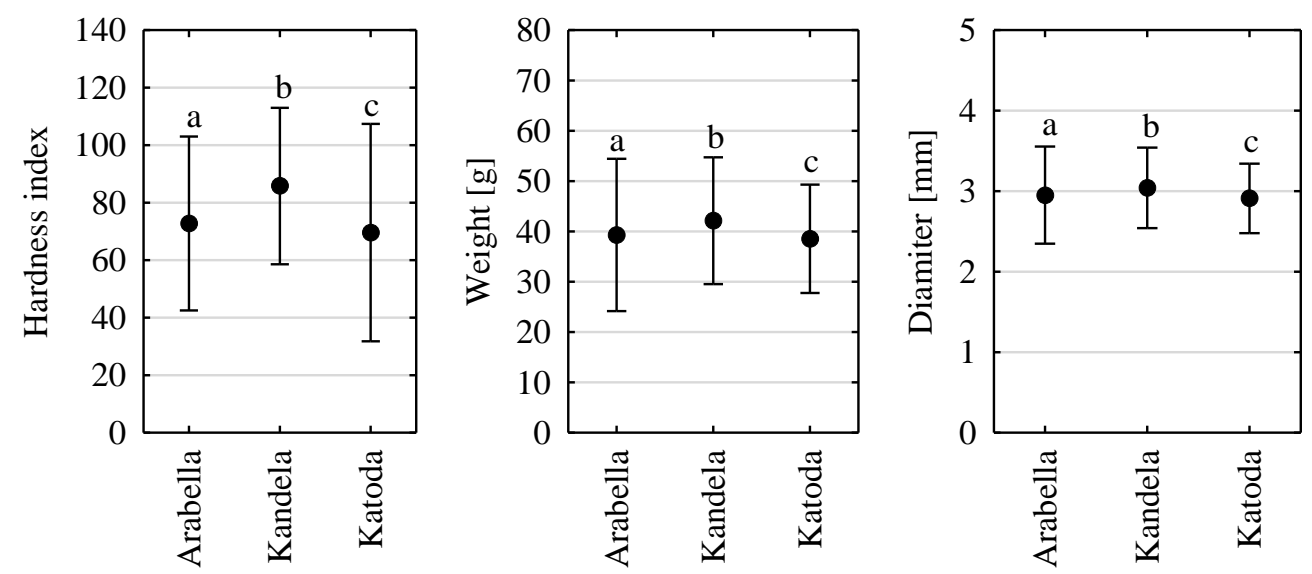

Fig. 1. Basic characteristics of kernel of the tested wheat varieties $\mathrm{a}, \mathrm{b}, \mathrm{c}-$ values marked with the same letter are not statistically significantly different $(\mathrm{p}>0.05)$ 
The tests demonstrated an effect of moisture content and the cultivar traits on the values of specific energy and values of efficiency of milling. The changes in the values of specific energy in relation to kernel moisture are presented in Fig. 2.

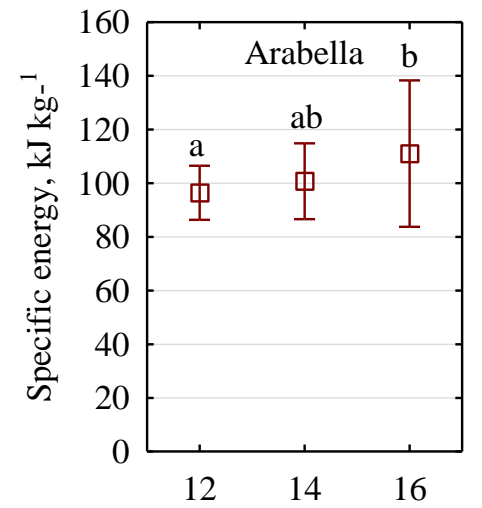

Moisture content, \%
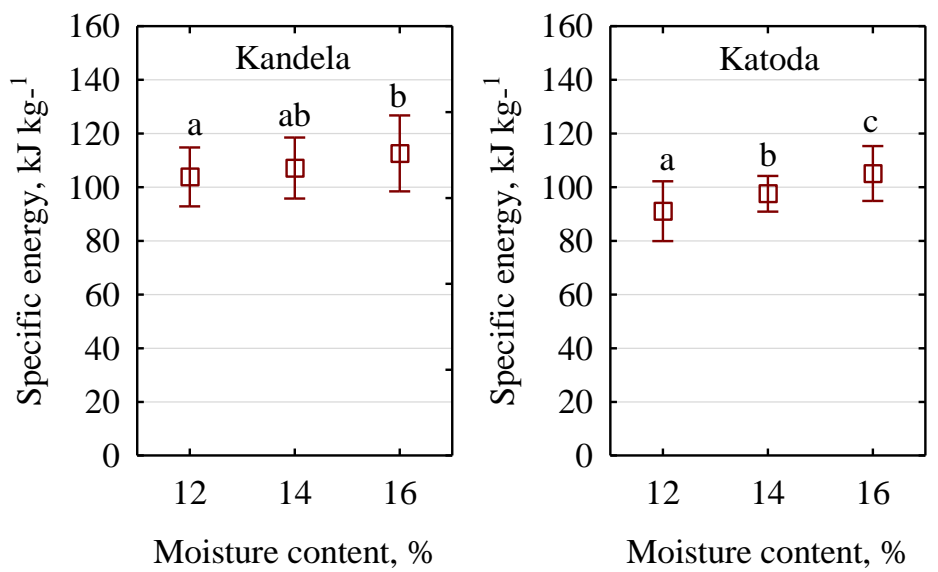

Fig. 2. Effect of kernel moisture content on specific energy for the tested wheat varieties $\mathrm{a}, \mathrm{b}, \mathrm{c}-$ values marked with the same letter are not statistically significantly different $(\mathrm{p}>0.05)$

The graph shows that in all the cases an increase of kernel moisture causes an increase of the values of specific energy. The lowest values of specific energy were recorded in the case of cultivar Katoda. This cultivar is characterised by the lowest value of hardness index. However cultivar Kandela has highest value of hardness index. Milling this variety showed the highest energy consumption.

The changes in the values of efficiency of milling in relation to kernel moisture are presented in Fig. 3. The graph shows that in all the cases an increase of kernel moisture causes a decrease of the efficiency of milling. The highest efficiency of milling was recorded in the case of cultivar Katoda.

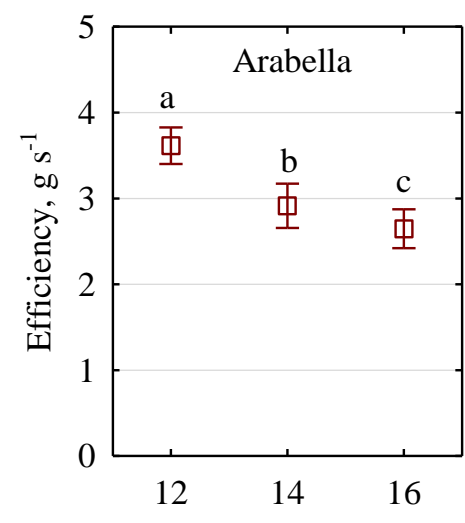

Moisture content, \%



Moisture content, \%

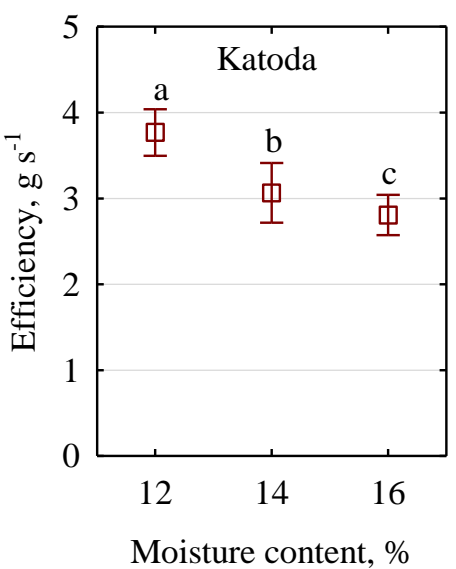

Moisture content, \%

Fig. 3. Effect of kernel moisture content on efficiency of milling process for the tested wheat varieties $\mathrm{a}, \mathrm{b}, \mathrm{c}-$ values marked with the same letter are not statistically significantly different $(\mathrm{p}>0.05)$

\section{CONCLUSION}

The study demonstrated a statistically significant effect of cultivar traits of the wheat cultivars studied on hardness index. The tests demonstrated an effect of moisture content and the cultivar traits on the values of specific energy and values of efficiency of milling. Increasing the moisture content of tempering wheat leads to increase specific energy of 
the milling operation for all species, while increasing moisture content leads to decrease efficiency. The lowest specific energy and highest efficiency of milling was recorded in the case of cultivar Katoda. The study indicates that, taking into account only the aspect of energy consumption, it is possible to select cultivars with low specific energy and high efficiency during milling, which in turn causes reducing the production costs, since hard wheat needs high specific energy and reduce the efficiency.

\section{REFERENCES}

Ahmed, Z. A., Nadulski, R., Kobus, Z., \& Zawiślak, K. (2015). The Influence of Grain Moisture Content on Specific Energy During Spring Wheat Grinding. Agriculture and Agricultural Science Procedia, 7 , 309-312.

BAŞLAR, M., Kalkan, F., Kara, M., \& Ertugay, M. F. (2012). Correlation between the protein content and mechanical properties of wheat. Turkish Journal of Agriculture and Forestry, 36(5), 601-607.

Bhat, N. A., Wani, I. A., Hamdani, A. M., Gani, A., \& Masoodi, F. A. (2016). Physicochemical properties of whole wheat flour as affected by gamma irradiation. LWT-Food Science and Technology, 71, 175-183.

Clarke, B., Rottger, A. (2016) Small mills in Africa. Selection, installation and operation of equipment, Food and Agriculture Organization of the United Nations. FAO. Roma. 1-23.

Dziki, D., Przypek-Ochab, D. (2009). Ocena energochłonności rozdrabniania ziarna pszenicy zróżnicowanego pod względem twardości. Inżynieria Rolnicza, 13, 61-67.

Dziki, D., Laskowski, J. (2005). The factors that influence the energy requirements of the grinding process of wheat grain. TEKA Komisji Motoryzacji i Energetyki Rolnictwa, 5, 55-64

Dziki, D., \& Laskowski, J. (2010). Study to analyze the influence of sprouting of the wheat grain on the grinding process. Journal of Food Engineering, 96(4), 562-567.

Dziki, D. (2011). Effect of preliminary grinding of the wheat grain on the pulverizing process. Journal of food engineering, 104(4), 585-591.

Dziki, D., Cacak-Pietrzak, G., Miś, A., Jończyk, K., \& Gawlik-Dziki, U. (2014). Influence of wheat kernel physical properties on the pulverizing process. Journal of food science and technology, 51(10), 2648-2655.

Hourston, J. E., Ignatz, M., Reith, M., Leubner-Metzger G., Steinbrecher, T. (2017). Biomechanical properties of wheat grains: the implications on milling. Journal of the Royal Society Interface, 14(126), 112.

Krasileva, K. V., Vasquez-Gross, H. A., Howell, T., Bailey, P., Paraiso, F., Clissold, L., ... \& Fosker, C. (2017). Uncovering hidden variation in polyploid wheat. Proceedings of the National Academy of Sciences, 201619268.

Patwa, A., Malcolm, B., Wilson, J., \& Ambrose, K. R. (2014). Particle size analysis of two distinct classes of wheat flour by sieving. Transactions of the ASABE, 57(1), 151-159.

Raigar, R. K., Prabhakar, P. K., \& Srivastav, P. P. (2017). Effect of Different Thermal Treatments on Grinding Characteristics, Granular Morphology and Yield of Ready-to-Eat Wheat Grits. Journal of Food Process Engineering, 40(2).

STATISTICA 12.0 (Data Analysis Software System), v. 6.1, StatSoft, Inc, Tulsa, OK, USA; http://www.statsoft.com. (2016).

Warechowska, M. (2014). Some physical properties of cereal grain and energy consumption of grinding. Agricultural Engineering, 1(149), 239-249.

Warechowska, M., Markowska, A., Warechowski, J., Miś, A., \& Nawrocka, A. (2016). Effect of tempering moisture of wheat on grinding energy, middlings and flour size distribution, and gluten and dough mixing properties. Journal of Cereal Science, 69, 306-312.

Warechowska, M., Warechowski, J., Skibniewska, K. A., Siemianowska, E., Tyburski, J., \& Aljewicz, M. A. (2016). Environmental factors influence milling and physical properties and flour size distribution of organic spelt wheat. Technical Sciences/University of Warmia and Mazury in Olsztyn, (19 (4)), 387-399 